\title{
Crises on coral reefs and in coral reef science in the 21st century: the need for a new peer-review system
}

\author{
Paul W. Sammarco \\ Louisiana Universities Marine Consortium (LUMCON), 8124 Hwy. 56, Chauvin, Louisiana 70344, USA
}

\begin{abstract}
Coral reef biota have suffered mass mortality globally in the last 30 yr. Causes include: (1) coral disease, (2) coral bleaching, (3) coastal nutrient enrichment, (4) over-fishing, and (5) mass mortality of grazing echinoids. In this paper, I examine data from a US funding agency, a global funding agency, and abstracting indices, and demonstrate why the peer review system has become dysfunctional under these circumstances. Research funding and the number of funded projects have not kept pace with increases in environmental problems, the increased researcher population and researcher demand, resulting in a chronic support gap. This has undermined trust, mutual support, and free-flow of information, and resulted in a poorly functioning review system. I examine the advantages and disadvantages of masking and the double-blinded review system, and recommend a more transparent review system - the reverse-blind review system (RBRS), utilizing (1) Lack of identity of authors/proponents to reviewers, to promote objectivity, (2) identification of reviewers to the authors/proponents, to promote accountability, (3) utilization of expert 'panel' members in grant proposal review, similar to the editorial system of scientific journals, each making direct recommendations to funding agencies, (4) elimination of grant panel meetings to help eliminate input by nonexperts and confounding group interactions and assign greater responsibility to funding bodies, and (5) allowing researchers to appeal decisions based on inaccurate or misleading information. Such a system would be fairer to the researchers, enhance research, and increase information exchange.
\end{abstract}

KEY WORDS: Coral $\cdot$ Peer review $\cdot$ Proposals $\cdot$ Manuscripts $\cdot$ Publishing $\cdot$ Funding $\cdot$ Panel $\cdot$ Appeal

\section{INTRODUCTION — the shifting sands of time}

Through the 1970s, much coral research might have been considered 'pure science', attempting to understand geological, physiological, and ecological processes in these complex ecosystems. Research funding appeared to be more accessible at that time, and information flow was more open. The need for environmental research and the impact of human activities on coral reefs was present but had a low profile, and it was not as pressing as in the late 20th and early 21st centuries. Perturbations to reefs receiving attention at that time included natural disasters such as hurricanes (e.g. Stoddart 1972, 1974, Baines et al. 1974, Roberts 1974), overfishing (e.g. Munro 1974, Kimmerer \& Durbin 1975, Pauly 1979, Woodley 1979, Parrish et al. 1983) and Acanthaster planci population explosions (Tsuda et al. 1970, Branham et al. 1971), and whether they were of human or natural origin (Kawecka-Lee, 1970, Hayashi \& Tatsuki 1975, Jones \& Randall 1979, Cameron \& Endean 1981, Birkeland 1982).

In the early 1980 s, mass mortalities of Diadema antillarum, a key grazer in the Caribbean (Sammarco 1980, 1982a,b), occurred (Lessios et al. 1984), causing mass mortalities of corals, population increases in benthic macro-algae, and the progression of benthic communities from one stable point, a healthy coral reef, to another-an algal ridge (Hughes et al. 1985, 1987, 1994a). Shortly thereafter, mass coral bleaching occurred at various points around the world (Glynn 1983, Cortes et al. 1984, Lasker et al. 1984, HoeghGuldberg 1999, Toscano et al. 2002). This increased in 
frequency and intensity with time (Hughes et al. 2003, Hoegh-Guldberg 2004, Goreau \& Hayes 2005, Goreau et al. 2005), in concert with El Niño Southern Oscillation (ENSO) events (Glynn \& Ault 2000, Diaz et al. 2001, Carleton 2003, Dore 2005).

In the mid 1970s to the early 1980s, first reports of coral diseases emerged (Garrett \& Ducklow 1975, Antonius 1976, 1981a,b, Ducklow \& Mitchell 1979, Laydoo 1984). The diversity of reported diseases and their geographic distribution expanded, and diseases were reported to cause widespread coral mortality, particularly in the Caribbean (Aronson \& Precht 2001, 2006, Rosenberg \& Loya 2004, Weil 2004, Weil et al. 2006). With a few exceptions (Richardson, 1998, Patterson et al. 2002), most confirmed causative pathogens remain unknown (Richardson \& Aronson 2002, Lafferty et al. 2004, Sutherland et al. 2004, Weil et al. 2006). Potential causes of these diseases have been widely debated, and despite the list of potential causes that have been proposed by experts in the field, little consensus has been reached on the subject (Shinn et al. 2000, Garrison et al. 2003, 2006, Griffin et al. 2003, Gochfeld et al. 2006, Jacobson 2006, Smith et al. 2006, Voss \& Richardson 2006, Lesser et al. 2007, Ward et al. 2007, Couch et al. 2008). Live coral cover on many reefs decreased over the ensuing decades to low levels. For example, Gardner et al. (2003) estimate that there has been a decrease in mean coral cover at the Caribbean sites they analyzed from 50 to $10 \%$. There was a $60 \%$ drop in live coral cover at Carysfort Reef in the Florida Keys (Dustan \& Halas 1987, Dustan et al. 2001, Porter et al. 2001), while a drop of up to $44 \%$ was measured at other sites in this system (Porter et al. 1993, Ogden et al. 1994), including, in the case of Acropora cervicornis, a drop from 96 to $12 \%$ cover (Williams \& Miller 2005). A $67 \%$ decrease was also observed in live coral cover in the Gilbert Islands (Indo-Pacific, Donner et al. 2006).

Since the beginning of the last quarter of the 20th century, environmental problems on coral reefs have grown, and questions regarding possible causes and solutions have increasingly drawn the attention of researchers. Progress in the major research areas has moved forward, but slowly, while the problems have worsened at an ever-increasing rate. Attempts to address and understand them are not keeping pace with the rush to initiate new protective regulations (Shinn 2004).

The purpose of this paper is to examine some possible reasons for the slow rate of progress in coral reef research, to address these problems, and to examine how scientists and government funding agencies may themselves have contributed to the slow rate. I use data derived from 2 research funding agencies and several abstracting indices as indicators of trends in coral reef science and their effects. I also examine review systems for research grants and the publication of scientific papers, and make recommendations for an alternate system that may be more appropriate for the field, particularly in light of today's funding climate and large researcher population.

\section{FUNDING HISTORY AND THE CURRENT STATUS}

\section{Research funding and number of researchers - a divergent pattern}

A database search, combined with requests to a variety of funding agencies worldwide, revealed that data on external support for coral reef research varied in their accessibility or availability. Long-term records were only readily available from the US National Science Foundation (NSF) and the World Bank. Other agencies researched, but not yielding data, included the Australian Marine Science and Technology Advisory Committee (AMSTAC), the Australian Research Council (ARC), the International Society for Reef Studies (ISRS) the US Dept. of Commerce National Oceanic and Atmospheric Administration (NOAA), the US Nature Conservancy, the UK Natural Environment Research Council (NERC), and the Deutsche Forschungsgemeinschaft (DFG).

Prior to 1975, levels of research funding appeared to be adequate for the needs of coral reef science. The number of researchers did not greatly exceed the support available. As time progressed, the number of researchers increased non-linearly, as indicated by the annual production of relevant dissertations and theses (Fig. 1a) and published scientific papers (Fig. 1b) involving coral. Two of the major causes of coral mortality within the past 25 years have been bleaching and coral disease. Research conducted on these phenomena and the number of researchers directing their attention to them also increased non-linearly (Figs. 2a,b, respectively). NSF funding for research in coral reef science, however, lagged behind the cumulative demand for such, as indicated by a similar increase but with a lower slope (Fig. 3). This delayed response in funding was mimicked by the World Bank, as indicated by the number of coral-related reports generated annually (Fig. 4) (data on annual funding from this source were too scant to be conclusive.) A non-linear increase in per-project funding by NSF did occur (Fig. 5), but the number of projects being funded increased only linearly (Fig. 6). This created an increasing gap between available resources and the number of researchers seeking funding, resulting in a 


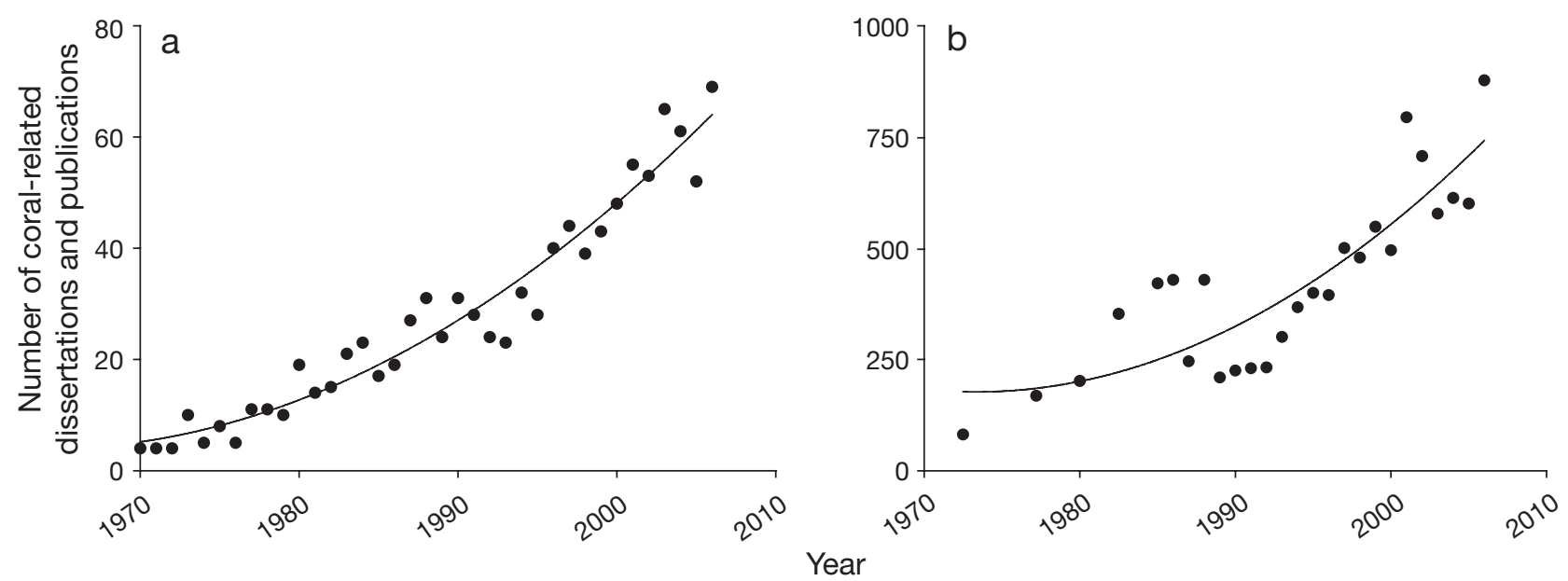

Fig. 1. (a) Number of $\mathrm{PhD}$ dissertations and MSc theses involving 'coral' produced per annum from 1970 to 2006 . Significant increase through time $\left(p<0.001,2\right.$ nd degree polynomial regression, $\left.Y=\left[1.31 \times 10^{5}\right]-133.05 X+0.03 X^{2}\right)$. Note the increase beginning in the mid-1970s, indicating an increase in the number of researchers in the field. Data derived from Dissertation Abstracts. (b) Number of scientific papers published in marine science regarding 'coral' from 1971 to 2006. Significant increase through time $\left(\mathrm{p}<0.001\right.$, 2nd degree polynomial regression, $\left.\mathrm{Y}=\left[2.10 \times 10^{6}\right]-\left[2.13 \times 10^{3}\right] \mathrm{X}+0.54 \mathrm{X}^{2}\right)$. Note the increase in publication frequency during the 1980s, indicating an increase in the number of researchers in the field. Data derived from CSA Illumina - Aquatic Science and Fisheries Abstracts, and Oceanic Abstracts

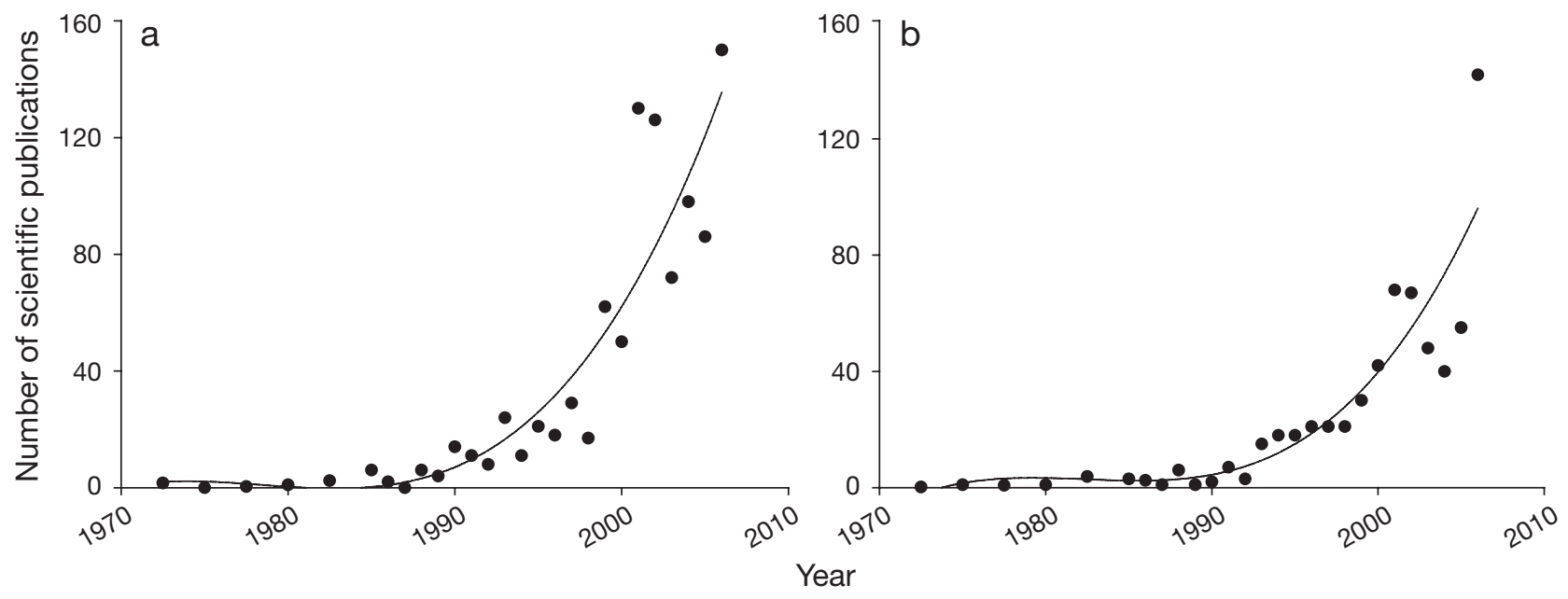

Fig. 2. (a) Number of scientific papers published on coral bleaching from 1971 to 2006. Significant increase through time $\left(\mathrm{p}<0.001\right.$, 3rd degree polynomial regression, $\left.\mathrm{Y}=\left[-5.36 \times 10^{7}\right]-\left[8.13 \times 10^{4}\right] \mathrm{X}-41.09 \mathrm{X}^{2}+0.01 \mathrm{X}^{3}\right)$. (b) Number of scientific papers published on coral disease from 1971 to 2006. Significant increase through time $(\mathrm{p}<0.001$, 3rd degree polynomial regression, $\left.\mathrm{Y}=\left[-5.84 \times 10^{7}\right]+\left[8.84 \times 10^{4}\right] \mathrm{X}-44.58 \mathrm{X}^{2}+0.01 \mathrm{X}^{3}\right) .(\mathrm{a}, \mathrm{b})$ Note sharp increase in frequency of publication in the $1990 \mathrm{~s}$. Data derived from CSA Illumina - Aquatic Science and Fisheries Abstracts, and Oceanic Abstracts

decreasing probability of being funded. Although research funding appeared to be following an increasing trend similar to demand, this relationship disappeared when the number of scientists generating the papers referred to above was compared with the number of projects funded by the NSF since 1970 (see Fig. 6); i.e. the number of projects funded increased linearly, but that was insufficient to keep pace with the number of investigators in the field. Basic funding increased, and the per-project funding increased, but the number of projects and of investigators being supported did not. It would be interesting to know whether funding patterns in coral reef science either slowed or advanced the observed ecological trends; unfortunately, it is not possible to determine this from the available data. During this same period, the frequency and intensity of environmental problems continued to increase. 


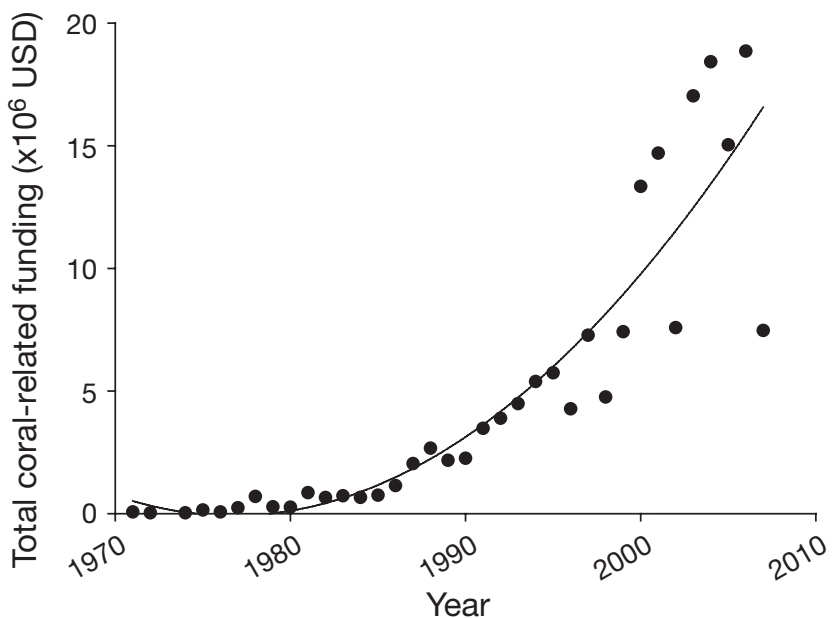

Fig. 3. Total amount of research funding (USD) allocated to projects involving 'coral' by the US National Science Foundation (NSF) from 1970 to 2007. Significant increase through time $(\mathrm{p}<0.001,2 \mathrm{nd}$ degree polynomial regression, $\mathrm{Y}=[7.11 \times$ $\left.\left.10^{10}\right]-\left[7.18 \times 10^{7}\right] \mathrm{X}+\left[1.82 \times 10^{4}\right] \mathrm{X}^{2}\right)$. Shape of curve generally tracks publication frequency, shown in Figs. 1-3, but slope is lower. Data derived from NSF archives

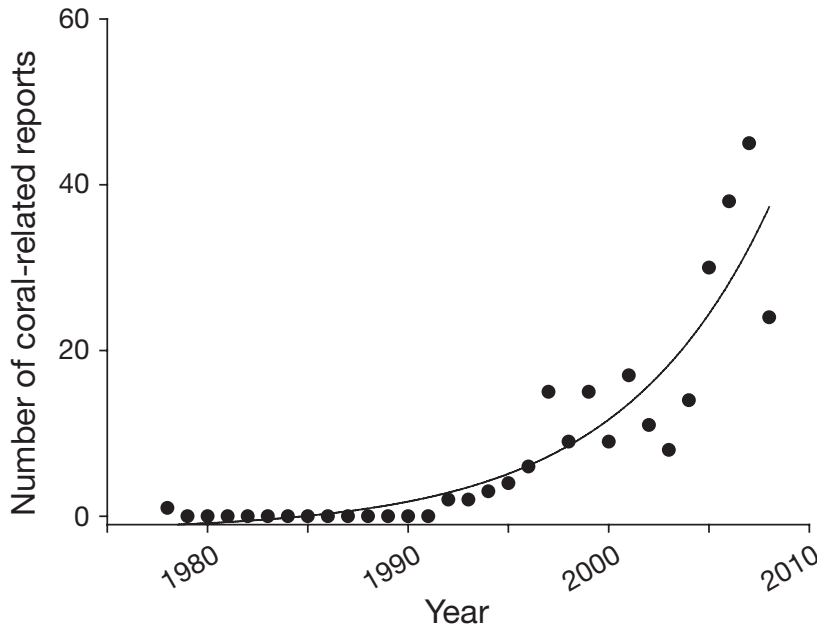

Fig. 4. Number of coral-related reports published by the World Bank (WB) from 1978 to 2007 as an indicator of WB funding. Significant increase through time $(\mathrm{p}<0.001$, exponential growth, single, 3-parameter analysis, $\mathrm{Y}=-1.76+$ $0.62^{[0.13 \mathrm{X}]}$ ). Increase follows NSF funding trend by 5 to $10 \mathrm{yr}$. Data derived from WB archives

This situation was aggravated by a general increase in the overall scientist population. Job availability did not keep pace with demand. In addition, an increasing number of graduate students and new PhDs were being attracted to coral reef science by the increasing visibility of environmental problems on coral reefs via media publicity. Thus, the divergence between the pool of researchers and available funding was exacerbated perhaps more than in some other fields where no

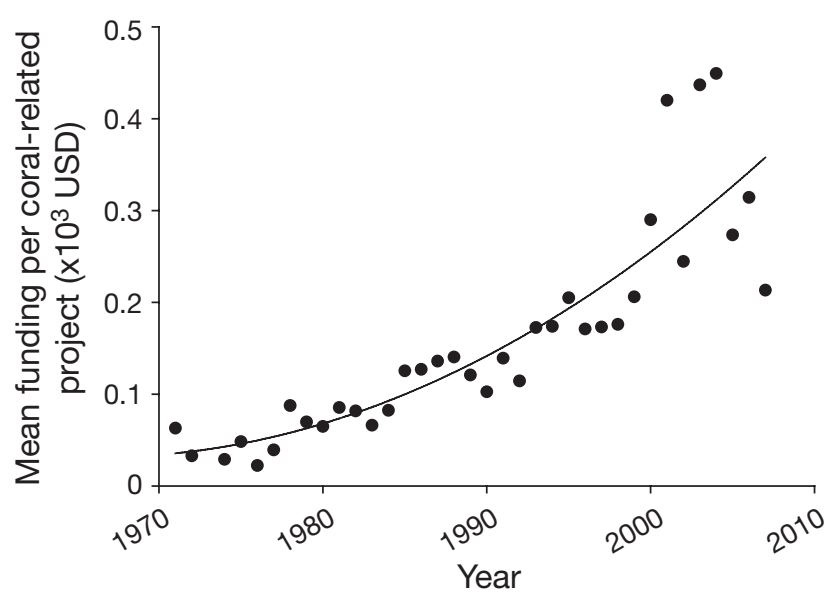

Fig. 5. Funds (USD) awarded per project by the US National Science Foundation (NSF) for projects involving 'coral' from 1970 to 2007 (mean). Significant increase through time ( $p<$ 0.001 , 2nd degree polynomial, $Y=\left[7.67 \times 10^{8}\right]-\left[7.80 \times 10^{5}\right] \mathrm{X}$ $+198.31 \mathrm{X}^{3}$ ). Note that the function is polynomial, generally tracking the overall funding trend shown in Fig. 4. In light of Fig. 6, this indicates that an increasing number of funds are being awarded to a proportionally smaller number of projects through time, while the researcher population is increasing non-linearly

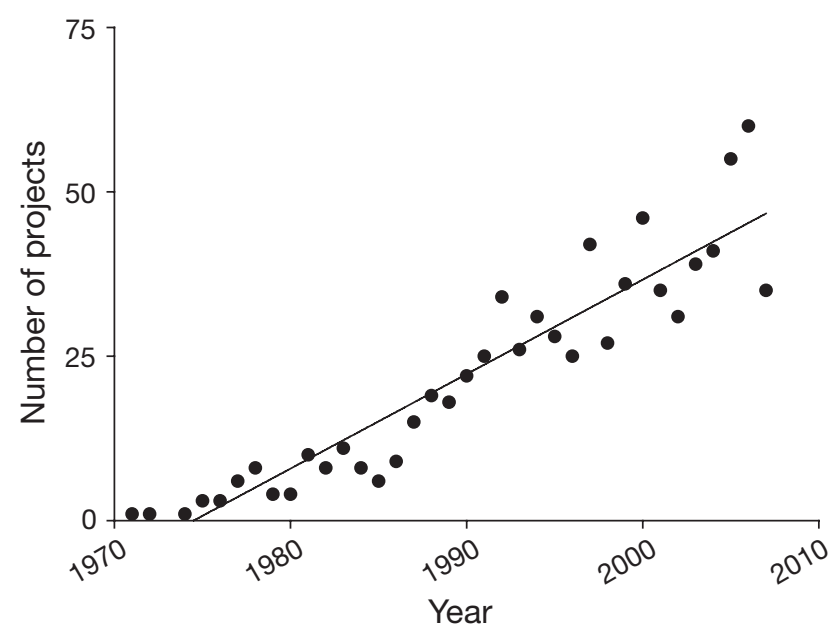

Fig. 6. Number of projects involving 'coral' funded by the US National Science Foundation (NSF) from 1970 to 2007. Significant increase through time $(\mathrm{p}<0.001$, linear regression, $\mathrm{Y}=$ $\left.\left[-2.84 \times 10^{3}\right]+1.44 \mathrm{X}\right)$. Note that the shape of the curve is linear, indicating that the number of projects is not tracking the demand for support shown in Figs. 1-4. Data derived from NSF archives

similar acute threat to the ecosystem existed. These conditions, along with a sense of urgency promoted by a highly perturbed ecosystem (see below) can create anxiety in the researcher population. This can cause a less than favorable setting for the grant proposal or manuscript review process and a negative feedback loop, in the end slowing down scientific progress. 
Many coral reef-related jobs currently advertised on a global basis relate to management of an increasing number of preserves and sanctuaries, which is a good sign. Unfortunately, the same amount of attention is not being given to research to determine what the activities or causal factors requiring management are.

\section{The sense of urgency - a confounding and exacerbating factor}

Investigators are now conducting research on a wide variety of coral reef systems that have suffered critical setbacks (Porter et al. 2001, Hoegh-Guldberg 2004). Risk (1999) contrasts this ecological crisis with 2 earlier ones-eutrophication in the Great Lakes and acid rains. He claims that these sister problems were addressed quickly and effectively, but that current problems with coral reefs have not been. A sense of urgency is creating a rush for research support through funding systems that either are not accommodating, or cannot accommodate, the demand to its full extent.

In the past, and for the most part the present, individual investigators worked within specialized fields, focusing on a single, critical issue contributing to the deterioration of reefs (e.g. disease, bleaching, nutrient enrichment, etc.), locally or regionally. The many factors causing these problems, however, are most likely not acting in isolation, but rather in concert (Sammarco 1996, Hughes \& Connell 1999, Szmant 2002, Chabanet et al. 2005, Pandolfi et al. 2005, Aronson \& Precht 2006, Hendee et al. 2006, Kappel 2006, Richmond et al. 2006). Thus, it is unlikely that a single-pronged approach to solving the reefs' problems could be totally effective (Sammarco 1994). The populations in this ecosystem are inter-linked, like the gears of a clock, and each environmental perturbation can move at least one of those gears. One gear moves, and many others move in synchrony, to a lesser or greater extent, depending upon the size of the gear-either in synchrony or in opposite directions. More likely, combined stressors can exert pressure until, together, they can force the system beyond some threshold whereby it moves to another stable point (Sutherland 1974, Vavrinec \& McNaught 2001, Burkepile \& Hay 2006, Pearse 2006, Hughes et al. 2007) from which it cannot readily rebound. Hughes et al. (1987, also see Hughes $1994 a, b)$ cite Jamaican reefs as an example of this. The effects of these stresses are likewise linked. The effect of any stressor on one species can in turn have effects on a multitude of other species ecologically linked to the first, and this effect will be multiplied through a variety of cascading ecological processes (e.g. grazing, competition for space, biological disturbance, recruitment, etc, see Sammarco 1980, 1982a,b).
Many coral reef researchers will in private admit that obstruction of their research proposals and manuscripts occurs, particularly those in critical or controversial areas. Borrowing of concepts from proposals also occurs, as it does in many branches of science. Under the circumstances of rapid ecosystem deterioration and inadequate funding, investigators can become territorial about their concepts and work and offer non-constructive comments in their reviews; Siegelman (1991) referred to such researchers as 'assassins'. Concern about infringement on concepts, experimental designs, and results - even from conference presentations - can grow. Information flow is thus retarded. Obstruction of manuscripts submitted for publication occurs at the review level (Siegelman 1991). Work that has been completed, whether funded or not, may not get published or may be delayed. Progress, results, and ideas do not get distributed to the scientific community in a timely fashion. The purpose of a review, however, is to determine whether the science is technically sound and the results are properly reported - not to determine whether the results agree with those of the reviewer or not, or whether they serve as a potential or perceived threat to the reviewer; yet this is sometimes how reviews are approached. A review is not a vote either, it is an opinion and should offer constructive advice (S. Shumway pers. comm.).

These negative interactions tend to discourage trust within the scientific community, and solutions to ecosystem problems further evade us.

\section{PEER REVIEW SYSTEMS}

\section{Problems with the current system}

Coral reef science is, and has been for decades, a newsworthy and topical area of research, producing numerous publications. Given the above issues, however, there needs to be a fundamental change in the review process for both manuscripts submitted for publication and research grant proposals submitted for funding. This would apply to specialist journals, sections of broader journals handling this area, and funding programs specializing in this area. Although the problems discussed above are not unique to the discipline, it would appear that the review system needs to be changed for journals specializing in coral reef science. Changing the manner in which such manuscripts are handled by journals with a broader scope is a more complex problem. The new system might be applied to manuscripts only from this specialty - or to all manuscripts received, to insure equitability in the review process. 
The current single-blind peer review (SBPR) system, in which the author's identity is known to the reviewer, but not vice versa, has been used throughout the last half of the 20th century and worked well for many years (Lock 1985); however, it is unfortunately somewhat less effective in the 2000s. Mainguy et al. (2005) of UNESCO report that the 'SBPR[...] is the currently accepted practice. Because SBPR can be vulnerable to sexism and nepotism[...], its ethical foundations have come under criticism; the method is frequently recognized to be biased against new ideas, women, young scientists, career changers, and scholars from less prestigious universities and/or from developing countries[...]' They recommend 2 policies to eliminate such bias-double-blind peer review (DBPR) and open peer review.

\section{Alternative review systems}

\section{Double-blind peer review (DBPR)}

The DBPR system has been used successfully in the medical sciences for decades. Here, authors are not identified to the reviewers, and reviewers are not identified to the authors. This system has worked well and produced some interesting and unexpected side effects. For example, one study examining thousands of reviews and publications under a DBPR system revealed that acceptance of manuscripts with a female senior author increased significantly (Budden et al. 2008, also see Mainguy et al. 2005). There is also evidence that DBPR-reviewed papers were cited more often than single-blind review papers (McNutt et al. 1990, Labande \& Piette 1994, Mainguy et al. 2005). A negative side effect is that the rejection rate can be higher with the double-blind (DB) system than the single-blind (SB) system, because reviewers cannot recognize the work of their friends and may mistake the work for being from competitors.

van Rooyen et al. (1998) attempted to determine whether concealing authors' identities from reviewers (blinding) and/or revealing the reviewer's identity to a co-reviewer (unmasking) affects the quality of reviews and the recommendation regarding publication. They found little difference in review quality between the masked and unmasked groups, and between the blinded and non-blinded groups. Masking did not affect recommendations regarding publication or the quality or timeliness of the reviews either. Side effects included refusal by some reviewers to participate, to avoid potentially straining collegial relationships with their peers.

On the other hand, Mainguy et al. (2005) said, 'Maintenance of trust within the international scientific community is crucial, not only for future scientific development, but also to continue the dialogue of civilizations. We believe that the current peer-review process, even though functional, can be, and should be, improved to bolster a more even playing field for all scientists. [...] We propose here that DBPR is [...] a reasonably fair process [and] also bears symbolic power that will go a long way to quell fears and frustrations, thereby generating a better perception of fairness and equality in global scientific funding and publishing. This will, in turn, help to keep research results more accessible for future generations.'

\section{Author masked review}

Justice et al. (1998) attempted to determine whether well-known authors receive less objective (poorer quality) reviews than lesser known authors. They found no significant difference in quality between masked and unmasked reviews nor was there any difference in the degree to which the review influenced the editorial decision. They also found that successfully masking the author is often difficult or impossible, depending upon the manner in which the manuscript or proposal had been constructed. In that study, manuscripts by better known authors were less likely to be successfully masked; but when manuscripts were successfully masked, review quality still did not differ. They concluded that masking reviewers to author identity does not improve review quality. The inability to mask the identity of well-known authors to reviewers may have contributed to the lack of effect.

Cho et al. (1998) found that success derived from the masking of authors' names is associated with reviewers' research experience. Using reviewers with less research and reviewing experience might increase masking success.

Reverse-blind peer review (RBPR)

I propose an alternate review system which might be useful under the circumstances: the reverse-blind peer review (RBPR) system, whereby the authors' identities are blinded to the reviewers, but the reviewers are required to sign their reports. The purpose would be to reduce anxiety about bias, increase accountability, and address the problem of poor review quality due to an imbalance in anonymity between reviewers and authors. One concern might be that more vulnerable junior reviewers might risk retaliation from authors if reviews are negative. Some editors argue that such would produce less than constructive reviews or even no criticism at all (S. Shumway pers. 
comm.). Godlee et al. (1998), however, tested the effect of this system on the quality of peer review and found that reviewers who were blinded to authors' identities and signed their reviews were less likely to recommend rejection. They also found that neither blinding reviewers to the authors' names and institutions nor identifying reviewers had any effect on the detection of errors.

\section{Suggestions for a new RBPR review system}

A new, more appropriate RBPR review system might include the differential identification of authors, proponents, reviewers, and panel members. Smith (1997), editor of the British Medical Journal, and D. Rennie, deputy editor (West) of the Journal of the American Medical Association (JAMA), have argued that open review, whereby authors are informed of their reviewers' identities, should be used. The editors of Cardiovascular Research also felt that open review would have to happen (Fabiato 1994), and several journals now use it. Smith (1997) felt that the argument for open review is ethical-once again, for increasing accountability and putting authors and reviewers in equal positions. He also states that 'Soon, closed peer review will look as anachronistic as unsigned editorials' (Smith 1997). I suggest that

- Authors or proponents be identified to the journal or agency

- Authors/proponents and their institutions not be identified to the reviewers

- In the case of proposals, resumes remain with and be judged by an expert panel member/editor, appointed by the agency, and by the agency itself

- In the same case, the expert panel member handle no more than 5 to 10 proposals within his/her field (see below)

- Reviewers be identified to authors and proponents.

The last of these would help to promote honesty and accountability in the review, and decrease the frequency of obstruction. It would eliminate the introduction of non-constructive ad hominem remarks and inaccurate or misleading information into the review system that may influence the agency, potentially leading to the rejection of a manuscript or proposal on false grounds. Those who have served on such panels know that a panel can be misled, either knowingly or unconsciously. Panel members or agency representatives can be misled by misinformation because they are often not as well-versed in a given research area. Transparency would most likely also encourage cordiality in the comments, as has been shown to occur in other disciplines (Walsh et al. 2000). Improved results will follow if reviewers know they will be held account- able for their comments by both the author/proponent and the agency.

Walsh et al. (2000) found that signed reviews, although being less timely, were of higher quality, and more likely to carry a positive recommendation for publication. McNutt et al. (1990) conducted a study where reviewers were asked (but not required) to sign reviews and authors' names and institutions were blinded. They found that $43 \%$ of the reviewers signed their reviews, that blinding (non-disclosure of the author's identities) did not affect the proportion of reviewers who signed, that review quality was higher, and that there was no association between signing and review quality. They concluded that blinding improved review quality. Similarly, Fisher et al. (1994) attempted to determine whether awareness of the author's identity creates a bias in favor of authors with more previous publications. They found that the number of previous articles by the senior author was significantly negatively correlated with blinded scores and editors' decisions, but not with non-blinded scores. They also found that the number of articles by the first author was significantly negatively correlated with editors' decisions but not with blinded or non-blinded scores. The identity of the authors was guessed correctly by $46 \%$ of blinded reviewers, mostly due to self-citations by the author and the reviewer's knowledge of their work. They concluded that blinded reviewers and editors in this study gave better scores to authors with more previous articles, that blinded reviewers may provide more unbiased reviews, and that non-blinded reviewers may be affected by various types of bias.

Labande \& Piette (1994) conducted a study to determine whether articles processed via a blinded peer review system receive either significantly more or fewer citations than those derived from a non-blinded system. They found that articles published in journals using blinded peer review were cited significantly more than articles published using a non-blinded sytem. Non-blinded peer review apparently suffers from type I error, i.e. publication of more papers that should not have been published, than do journals using blinded peer review.

\section{DECISIONS ON FUNDING}

\section{Independent panel members as 'editors' and elimination of panel meetings}

With respect to research funding, I question the need for panel meetings. The award of funding to support research (or, for that matter, the publication of a manuscript) is a matter between the agency (or the journal) 
and the proponent. The role of panels is that of an intermediate group that helps the agency to make decisions, but also insulates it from some of the responsibility regarding decision-making; but as a group, they can sometimes cloud issues and recommendations made by the reviewers. It is difficult for panel members to devote their full attention to each of the proposals presented to them, particularly if the number under consideration is high (on the order or hundreds) and if members are assigned reporting tasks with short deadlines within the meeting. In addition, there are inter-personal and group dynamics that occur within panels that can confound the decision-making process.

A more efficient model would be one similar to that of the journal editorial system

- One to 3 individuals chosen by the funding agency would handle a subset of proposals in his/her area of expertise and have them externally reviewed. The proposals would be processed in the same manner as manuscripts submitted for publication

- The panel member and the reviewers would be identified to authors/proponents, to promote accountability and decrease the probability of conflict of interest

- This panel member would make recommendations directly to the agency

- There would be no panel meeting to discuss the whole spectrum of submitted proposals and their reviews. This would eliminate any potential confounding interactions resulting from discussions between people lacking the specific expertise required to assess the proposals. Although it is possible that constructive information can be contributed by non-experts, I believe from experience that confounding information is more frequent

- The agency representatives would make the final decision on funding for a given proposal. This will return greater responsibility to the agency for their decisions. Panel membership would be completely rotated approximately every $3 \mathrm{yr}$, replacing one third of the membership annually to promote continuity and the retention of 'corporate memory' within the system. Permanent panels are not recommended; nor is total annual rotation of members.

\section{Funding high-risk science}

Panels do not always support the most innovative proposed research, particularly when overwhelmed with a large number of proposals. Cutting-edge proposals are often deemed 'too risky' and are prone to being dismissed. Those proposals that are 'tried and true', following known, well-tread paths and offering much preliminary data receive high ratings and are often regarded as 'sure bets' with guaranteed results, receiving high recommendations for funding.

However, some funds should be set aside to support well-founded, cutting-edge, higher risk proposals, provided that they are based on solid science and show great promise, despite the absence of extensive preliminary data. Such projects should be acceptable to the agencies in order to move our understanding of causative factors of coral reef decline forward as rapidly as possible.

\section{Appeals}

In any system requiring judgment, accountability is critical. In the case of rejection, the proponents should have the right to appeal the decision of the agency. They should also be permitted the right of rebuttal and to personally address agency representatives, panel members, and the reviewers, if necessary. For example, in Australia during the early 1980s, AMSTAC was responsible for making recommendations for funding marine science research. Proponents were sometimes invited to meet with the committee personally to address questions raised by the reviewers. This allowed proponents to help insure the accuracy of the information received by the committee, and opened the proposal to further discussion and review. The system is still used successfully today by the Australian Research Council (ARC), but only in a limited number of cases where large-scale funding is under consideration. Such a system could conceivably create a burden for the funding agency, but the mere availability of such an option to proponents might help to insure more accurate reviewing and justifiable decision-making.

\section{CONCLUSIONS}

For both proposals and manuscripts in coral reef science, information flow needs to increase. If obstruction of publications or proposals is occurring, it must be eliminated. Science cannot progress if the experiments are not performed, or the results do not reach the scientific community for debate or verification. Science generally progresses in small steps. If any of those steps are eliminated or stalled, overall progress is impeded. The adage still holds: 'We stand on the shoulders of those who came before us'. In our own climb, if we remove any of the shoulders of our colleagues when such is unmerited, it becomes more difficult to reach the objectives we have defined for ourselves. We must learn from each other's successes as 
well as each other's mistakes. The complexity of issues in this ecosystem makes it unlikely that any one scientist will provide the ultimate answers to the reefs' problems. We need to mature as a scientific community and work together if we truly care about seeing our ecosystem survive this century.

\section{LITERATURE CITED}

Antonius A (1976) Diseased corals: reef destruction. Umschau in Wissenschaft und Technik 76:493-494

Antonius A (1981a) The 'band' diseases in coral reefs. In: Gomez ED, Birkeland CE, Buddemeier RW, Johannes RE, Marsh JA Jr, Tsuda RT (eds) The reef and man. Proc 4th Int Coral Reef Symp, Manila 2:7-14

Antonius A (1981b) Coral reef pathology: a review. In: Gomez ED, Birkeland CE, Buddemeier RW, Johannes RE, Marsh JA Jr, Tsuda RT (eds) The reef and man. Proc 4 th Int Coral Reef Symp, Manila 2:3-6

Aronson RB, Precht WF (2001) White-band disease and the changing face of Caribbean coral reefs. Hydrobiologia 460:25-38

Aronson RB, Precht WF (2006) Conservation, precaution, and Caribbean reefs. Coral Reefs 25:441-450

Baines GBK, Beveridge PJ, Maragos JE (1974) Storms and island building at Funafuti Atoll, Ellice Islands. Proc Second Int Symp on Coral Reefs, Vol 2, p 485-496

Birkeland C (1982) Terrestrial runoff as a cause of outbreaks of Acanthaster planci (Echinodermata: Asteroidea). Mar Biol 69:175-185

Branham JM, Reed SA, Bailey JM, Caperon J (1971) Coraleating sea stars Acanthaster planci in Hawaii. Science 172:1155-1157

Budden AE, Tregenza T, Aarssen LW, Koricheva J, Leimu R, 6 Lortie CJ (2008) Double-blind review favours increased representation of female authors. Trends Ecol Evol 23:4-6

Burkepile DE, Hay ME (2006) Herbivore vs. nutrient control of marine primary producers: context-dependent effects. Ecology 87:3128-3139

Cameron AM, Endean R (1981) Renewed population outbreaks of a rare and specialized carnivore (the starfish Acanthaster planci) in a complex high-diversity system (the Great Barrier Reef). In: Gomez ED, Birkeland CE, Buddenmeier RW, Johannes RE, Marsh JA Jr, Tsuda RT (eds) The reef and man. Proc 4th Int Coral Reef Symp, Manila 2:593-596

> Carleton AM (2003) Atmospheric teleconnections involving the Southern Ocean. J Geophys Res C 108:8080

Chabanet P, Adjeroud M, Andrefouet S, Bozec JM, Ferraris J, Garcia-Charton J, Schrimm M (2005) Human-induced physical disturbances and their indicators on coral reef habitats: A multi-scale approach. Aquat Living Resour 18: 215-230

Cho A, Justice AC, Winker MA, Berlin JA and others (1998) Masking author identity in peer review: What factors influence masking success? J Am Med Assoc 280: 243-245

Cortes J, Murillo MM, Guzman HM, Acuna J (1984) Loss of zooxanthellae and death of corals and other reef organisms on the Caribbean and Pacific coasts of Costa Rica (SPA). Rev Biol Trop 32:227-231

Couch CS, Mydlarz LD, Harvell CD, Douglas NO (2008) Variation in measures of immunocompetence of the sea fan coral, Gorgonia ventilina, in the Florida Keys. Mar Biol 155:281-292
Diaz HF, Hoerling MP, Eischeid JK (2001) ENSO variability, teleconnections and climate change. Int J Climatol 21: 1845-1862

Donner S, Kirata T, Vieux C (2006) The 2004 coral bleaching in the Gilbert Islands: Connecting satellite prediction and coral cover surveys. EOS Trans Am Geophys Union 87, Ocean Sci Meet Suppl, Abstract OS14E-01

Dore MHI (2005) Climate change and changes in global precipitation patterns: What do we know? Environ Int 31: $1167-1181$

> Ducklow HW, Mitchell R (1979) Observations on naturally and artificially diseased tropical corals: a scanning electron microscope study. Microb Ecol 5:215-223

Dustan P, Halas JC (1987) Changes in the reef-coral community of Carysfort Reef, Key Largo, Florida: 1974-1982. Coral Reefs 6:91-106

Dustan P, Dobson E, Nelson G (2001) Landsat thematic mapper: Detection of shifts in community composition of coral reefs. Conserv Biol 15:892-902

$>$ Fabiato A (1994) Anonymity of reviewers. Cardiovasc Res 28:1134-1139

- Fisher M, Friedman SB, Strauss B (1994) The effects of blinding on acceptance of research papers by peer review. J Am Med Assoc 272:143-146

Gardner TA, Cote IM, Gill JA, Grant A, Watkinson AR (2003) Long-term region-wide declines in Caribbean corals. Science 301:958-960

Garrett T, Ducklow H (1975) Coral diseases in Bermuda. Nature 253:349-350

Garrison VH, Shinn EA, Foreman WT, Griffin DW and others (2003) African and Asian dust: from desert soils to coral reefs. Bioscience 53:469-480

Garrison VH, Kellogg CA, Carr RS, Foreman WT and others (2006) Do persistent organic pollutants, metals, and microbes transported with African dust contribute to disease on coral reefs? EOS Trans Am Geophys Union 87, Ocean Sci Meet Suppl, Abstract OS24L-01

Glynn PW (1983) Extensive 'bleaching' and death of reef corals on the Pacific coast of Panama. Environ Conserv 10:149-154

> Glynn PW, Ault JS (2000) A biogeographic analysis and review of the far eastern Pacific coral reef region. Coral Reefs 19:1-23

Gochfeld D, Miller J, Olson JB (2006) Variability in susceptibility and response to dark spot syndrome in Siderastrea siderea. EOS Trans Am Geophys Union 87, Ocean Sci Meet Suppl, Abstract OS26G-15

> Godlee F, Gale CR, Martyn CN (1998) Effect on the quality of peer review of blinding reviewers and asking them to sign their reports: a randomized control trial. J Am Med Assoc 280:237-240

Goreau TJF, Hayes RL (2005) Global coral reef bleaching and sea surface temperature trends from satellite-derived hotspot analysis. World Resour Rev 17:254-293

Goreau TJ, Hayes RL, McAlllister D (2005) Regional patterns of sea surface temperature rise: implications for global ocean circulation change and the future of coral reefs and fisheries. World Resour Rev 17:350-374

Griffin DW, Kellogg CA, Garrison VH, Shinn EA (2003) The global transport of dust. Am Sci 90:228-235

Hayashi K, Tatsuki T (1975) Acanthaster planci plague in Japan. Bull Mar Parks Res Stn 56:10-13

Hendee JC, Florit L, Jankulak M, Stabenau ER (2006) Integrating in situ, satellite and other data sources for marine protected area decision support and coral reef research. EOS Trans Am Geophys Union 87, Ocean Sci Meet Suppl, Abstract OS13E-06 
Hoegh-Guldberg O (1999) Climate change, coral bleaching, and the future of the world's coral reefs. Mar Freshw Res 50:839-866

Hoegh-Guldberg O (2004) Coral reefs in a century of rapid environmental change. Symbiosis 37:1-31

Hughes TP (1994a) Catastrophes, phase shifts, and largescale degradation of a Caribbean coral reef. Science 265:1547-1551

Hughes TP (1994b) Coral reef degradation: a long-term study of human and natural impacts. In: Ginsburg, RN (ed) Colloquium on global aspects of coral reefs: health, hazards and history. Symp Proc, Miami, FL, p 208-213

Hughes TP, Connell JH (1999) Multiple stressors on coral reefs: A long-term perspective. Limnol Oceanogr 44:932-940

Hughes TP, Keller BD, Jackson JBC, Boyle MJ (1985) Mass mortality of the echinoid Diadema antillarum Philippi in Jamaica. Bull Mar Sci 36:377-384

Hughes TP, Reed DC, Boyle MJ (1987) Herbivory on coral reefs: community structure following mass mortalities of sea urchins. J Exp Mar Biol Ecol 113:39-59

Hughes TP, Baird AH, Bellwood DR, Card M and others (2003) Climate change, human impacts, and the resilience of coral reefs. Science 301:929-933

Hughes TP, Rodrigues MJ, Gellwood DR, Ceccarelli D and others (2007) Phase shifts, herbivory, and the resilience of coral reefs to climate change. Curr Biol 17:360-365

Jacobson DM (2006) Fine-scale temporal and spatial dynamics of a Marshall Islands coral disease outbreak: Evidence for temperature forcing. EOS Trans Am Geophys Union 87 Ocean Sci Meet Suppl, OS46N-20

Jones RS, Randall RH (1979) A study of biological impact caused by natural and man-induced changes on a tropical reef. Tech Rep Univ Guam Mar Lab, no 7

Justice AC, Cho MK, Winker MA, Berlin JA and others (1998) Does masking author identity improve peer review quality? A randomized controlled trial. J Am Med Assoc 280:240-242

Kappel CV (2006) Threats to marine biodiversity and considerations for its conservation: from species to seascapes. $\mathrm{PhD}$ dissertation, Stanford University, Palo Alto, CA

Kawecka-Lee H (1970) Kozmar Pacyfiku (The Pacific nightmare). Przegl Zool 14:402-403

Kimmerer WJ, Durbin WW Jr (1975) The potential for additional marine conservation districts on Oahu and Hawaii. Sea Grant Tech Rep, Hawaii Univ, no. 76-03

Laband DN, Piette MJ (1994) A citation analysis of the impact of blinded peer review. J Am Med Assoc 272:147-149

Lafferty KD, Porter JW, Ford SE (2004) Are diseases increasing in the ocean? Annu Rev Ecol Evol Syst 35:31-54

Lasker HR, Peters EC, Coffroth MA (1984) Bleaching of reef coelenterates in the San Blas Islands, Panama. Coral Reefs 3:183-190

Laydoo R (1984) Inference of a 'white band' epidemic in the elkhorn coral, Acropora palmata, population in Tobago, West Indies. Proc Assoc Isl Mar Lab Carib, 18th meeting, Abstract

Lesser MP, Bythell JC, Gates RD, Johnstone RW, HoeghGuldberg O (2007) Are infectious diseases really killing corals? Alternative interpretations of the experimental and ecological data. J Exp Mar Biol Ecol 346:36-44

Lessios HA, Cubit JD, Robertson DR, Shulman MJ, Parker MR, Garrity SD, Levings SC (1984) Mass mortality of Diadema antillarum on the Caribbean coast of Panama. Coral Reefs 3:173-182

Lock S (1985) A difficult balance: editorial peer review in medicine. Nutfield Provincial Hospitals Trust, London
Mainguy G, Motamedi MR, Mietchen D (2005) Peer reviewthe newcomers' perspective. PLoS Biol 3:e326

McNutt RA, Evans AT, Fletcher RH, Fletcher SW (1990) The effects of blinding on the quality of peer review. A randomized trial. J Am Med Assoc 263:1371-1376

Munro JL (1974) The biology, ecology, exploitation and management of Caribbean reef fishes. Scientif. Rep. of the ODA/UWI Fisheries Ecology Res. Project: 1969-1973. Part 5. The biology, ecology and bionomics of Caribbean reef fishes. Summary of biological and ecological data pertaining to Caribbean reef fishes. Res Rep Zool Dept. Univ West Indies, No 3(Pt. 5m)

Ogden JC, Porter JW, Smith NP, Szmant AM, Jaap WC, Forcucci D (1994) A long-term interdisciplinary study of the Florida Keys seascape. Bull Mar Sci 54:1059-1071

Pandolfi JM, Jackson JBC, Baron N, Bradbury RH and others (2005) Are US coral reefs on the slippery slope to slime? Science 307:1725-1726

Parrish JD, Hayes TA, Hourigan TF, Walsh DJ (1983) Assessing effects of small-scale reef fisheries: an island example. 17th Meet Assoc Island Mar Laboratories Caribbean, Miami, FL

> Patterson KL, Porter JW, Ritchie KB, Polson SW and others (2002) The etiology of white pox, a lethal disease of the Caribbean elkhorn coral, Acropora palmata. Proc Natl Acad Sci USA 99:8725-8730

Pauly D (1979) Theory and management of tropical multi-species stocks: a review, with emphasis on the Southeast Asian demersal fisheries. ICLARM Stud Rev No. 1

> Pearse JS (2006) Ecological role of purple sea urchins. Science 314:940-941

Porter JW, Meier OW, Walton Smith FG (1993) Quantification of loss and change in Floridian reef coral populations. In Global aspects of coral reefs: health, hazards, and history. University of Miami, Miami Press, Miami, p M22-M28

> Porter JW, Dustan P, Jaap WC, Patterson KL and others (2001) Patterns of spread of coral disease in the Florida Keys. Hydrobiologia 460:1-24

- Richardson LL (1998) Coral diseases: What is really known? Trends Ecol Evol 13:438-443

Richardson LL, Aronson RB (2002) Infectious diseases of reef corals. Proc Ninth Int Coral Reef Symp, Bali, Oct 2000, Vol 2, p 1225-1230

Richmond RH, Ostrander GK, Downs C (2006) Identifying and measuring sub-lethal effects of multiple stressors on corals and coral reefs. EOS Trans Am Geophys Union 87, Ocean Sci Meet Suppl, Abstract OS24L-05

Risk MJ (1999) Paradise lost: how marine science failed the world's coral reefs. Mar Freshw Res 50:831-837

Roberts HH (1974). Variability of reefs with regard to changes in wave power around an island. Proc 2nd Int Coral Reef Symp, Vol 2

Rosenberg E, Loya Y (2004) Coral health and disease. Springer, New York

Sammarco PW (1980) Diadema and its relationship to coral spat mortality: grazing, competition, and biological disturbance. J Exp Mar Biol Ecol 45:245-272

Sammarco PW (1982a) Grazing by Diadema and its effects on algal community structure: diversity and grazing pressure. J Exp Mar Biol Ecol 65:83-105

> Sammarco PW (1982b) Echinoid grazing as a structuring force in coral communities: whole reef manipulations. J Exp Mar Biol Ecol 61:31-55

Sammarco PW (1994) The multiple-team approach to scientific problem solving: an effective paradigm. In: Sammarco PW, Heron ML (eds) The bio-physics of marine larval dispersal. Am Geophys Union, Wash DC, p 1-4 
Sammarco PW (1996) Comments on coral reef regeneration, bioerosion, biogeography, and chemical ecology: future directions. J Exp Mar Biol Ecol 200:135-168

Shinn EA (2004) The mixed value of environmental regulations: Do acroporid corals deserve endangered species status? Mar Pollut Bull 49:531-533

Shinn EA, Smith GW, Prospero JM, Betzer P, Hayes ML, Garrison V, Barber RT (2000) African dust and the demise of Caribbean coral reefs. Geophys Res Lett 27:3029-3032

Siegelman SS (1991) Assassins and zealots: variations in peer review. Special report. Radiology 178:637-642

Smith JE, Shaw M, Edwards RA, Obura D, and others (2006) Letter: Indirect effects of algae on coral: algaemediated, microbe-induced coral mortality. Ecol Lett 9: 835-845

Smith R (1997) Peer review: reform or revolution? Time to open up the black box of peer review. BMJ 315:759-760

Stoddart DR (1972) Catastrophic damage to coral reef communities by earthquake. Nature 239:51-52

Stoddart DR (1974) Post-hurricane changes on the British Honduras reefs: re-survey of 1972. Proc Second Int Coral Reefs Symp, Vol 2, p 473-483

Sutherland JP (1974) Multiple stable points in natural communities. Am Nat 108:859-873

Sutherland KP, Porter JW, Torres C (2004) Disease and immunity in Caribbean and Indo-Pacific zooxanthellate corals. Mar Ecol Prog Ser 266:273-302

Szmant AM (2002) Nutrient enrichment on coral reefs: Is it a major cause of coral reef decline? Estuaries 25:743-766

Toscano MA, Liu G, Guch IC, Casey KS, Strong AE, Meyer JE (2002) Improved prediction of coral bleaching using highresolution HotSpot anomaly mapping. In: Moosa MK, Soe-

Editorial responsibility: Konstantinos Stergiou, Thessaloniki, Greece modihardjo S, Soegiarto A, Romimohtarto K, Nontji A, Suharsono S (eds), Proc 9th Int Coral Reef Symp, Bali, 2: 1143-1147

Tsuda RT, Cheney DP, Marsh JA, Struck MR (1970) Acanthaster planci crown of thorns starfish: resurvey of Yap. University of Guam, Agana

van Rooyen S, Godlee F, Evans S, Smith R, Black N (1998) Effect of blinding and unmasking on the quality of peer review: a randomized trial. J Am Med Assoc 280: 234-237

Vavrinec J, McNaught D (2001) Alternate stable states and the management of the green sea urchin Strongylocentrotus droebachiensis in Maine. Gulf Mex Sci 19:193

> Voss JD, Richardson LL (2006) Nutrient enrichment enhances black band disease progression in corals. Coral Reefs 25: 569-576

> Walsh E, Rooney M, Appleby L, Wilkinson G (2000) Open peer review: a randomized controlled trial. Br J Psychiatry 176:47-51

> Ward JR, Kim K, Harvell CD (2007) Temperature affects coral disease resistance and pathogen growth. Mar Ecol Prog Ser 329:115-121

Weil E (2004) Coral reef diseases in the wider Caribbean. In: Rosenberg E, Loya Y (eds) Coral health and disease. Springer, New York, p 35-68

Weil E, Smith G, Gil-Agudelo DL (2006) Status and progress in coral reef disease research. Dis Aquat Org 69:1-7

> Williams DE, Miller MW (2005) Coral disease outbreak: Pattern, prevalence and transmission in Acropora cervicornis. Mar Ecol Prog Ser 301:119-128

Woodley JD (1979) The effects of trap-fishing on reef communities in Jamaica. Proc Assoc Island Mar Laboratories Caribbean, Mayaguez, p 27

Submitted: October 10, 2007; Accepted: August 6, 2008

Proofs received from author(s): September 25, 2008 